\title{
The effect of unethical behavior on brand equity
}

\author{
Seyedeh Faezeh Rezazadeh Baei ${ }^{\mathbf{a}^{*}}$ and Zeinolabedin Rahmani ${ }^{\mathrm{b}}$
}

${ }^{a}$ Master of Business Management (Marketing), Firuzkouh Branch, Islamic Azad University, Firuzkouh, Iran ${ }^{b}$ Professor of Payame noor University, PhD in Business Management

\section{H R O N I C L E}

Article history:

Received January 20, 2015

Received in revised format 16

February 2015

Accepted 10 April 2015

Available online

April 122015

Keywords:

Equity

Brand

Unethical Behavior

Factor Analysis

\begin{abstract}
A B S T R A C T
This study explains the components of ethical behavior and their impacts on life insurance companies in province of Mazandaran, Iran. There were 367 insurance representatives and the study selects a sample of 187 ones based on Cochran formula and 2 questionnaires were distributed among them. The first questionnaire, unethical behavior, includes 8 items including Bribery, Cheating, Deception, Interact with colleagues, Act as social behavior, Uncommitted to firm and Irresponsibility. In addition, the questionnaire of brand equity contains three components of Awareness, Perceived quality and Loyalty. Using structural equation modeling, the study has determined that the effects of cheating and deception on unethical behaviors were not confirmed but the effects of other factors, bribery, interact with colleagues, act as social behavior, uncommitted to firm and irresponsibility on unethical behavior were confirmed. In addition, three components of Awareness, Perceived quality and Loyalty had positive relationship with brand equity.
\end{abstract}

\section{Introduction}

University researchers and business managers have introduced ethical values as missing link of today's economy and they have considered it as an important strategy to create the lost trust (Alwani \& Ghasemi, 1997; Backman, 1988; Pappu et al., 2005; Bravo Gil et al., 2007; Keller et al., 2011). Service businesses may have a positive effect on customer perceptions respecting ethical traits. Hence, organizational ethical behavior leads to make and maintain stable relationships between organizations and their customers. During the past few years, the increasing trend on unethical behaviors among businesses has created concerns and tension for managers because the unethical behaviors in one hand may destroy the company's brand personality and, on other hand, it may decrease the reputation of the brand, accordingly. It leads not to purchase again and sanctions and punishment to business by customers. (Román \& Ruiz, 2005). Thus, business ethics perceived by customers influence on trust, satisfaction and loyalty and, consequently, effect on brand equity (Kotler, 2000). Vendor as the first interface has a significant impact on customer perception of the reliability of the service provider and 
the service and ultimately customer benefit in maintaining its relationship with the vendor organization (Haghighi et al., 2011; Louis \& Lombart, 2010). Brand equity is an asset that keeps companies' values and leads to customer loyalty. Aaker (1996) introduced concept of brand equity as "assets (or debt) associated to a brand that the brand-linked to the name or symbol of it which will increase the value of goods/services or reduce it”. He described the dimensions of brand equity as loyalty, brand awareness, perceived quality, brand bonds and other assets associated with the brand. Wood (2000) believes that an attempt to define the relationships between customers and brands may lead to creation of the concept of "brand equity". Others described brand equity as consumer prioritization of a brand in comparison to others in one product category. According to Gill and Dawra (2010) brand equity is the value of a brand added to the product.

\subsection{Dimensions of brand equity}

\section{Awareness and brand associations}

According to Aaker (1997) brand awareness has close relationship with brand associations. Gill and Dawra (2010) believe brand association make a sense of values and beliefs about brands. Atilgan et al. (2005) express brand associations has an impact on consumer loyalty and creates value for consumers and companies. Aaker (1991) defines brand awareness as consumers' ability to recall or remember and identify specific brand in a product category like remembering a brand name like coca cola.

\section{Perceived quality}

Perceived quality can be defined as perception of customers of better goods quality or service to other brands, which does not include technical dimension and it is one of brand equity components. Though, high perceived value push consumers to select a product or service from other competitors. Aaker (1991) defines perceived quality as perception of customers of higher or overall quality of goods or service that is according to his or her goal. He describes in his model that perceived quality effects on brand equity through: (1) a reason to buy the brand (2) distinction / positioning (3) premium price (4) the interest of distribution channel members to use the product with higher perceived quality (5) brand development.

\section{Brand loyalty}

According to Aaker's brand equity model (1991) brand loyalty was defined as business leverage to reduce marketing expenses, attract new customers by creating awareness and reassurance and the time to respond to competitive threats mentioned. Gill and Dawra (2010) suggest that loyalty directly could increase the brand equity and other variables, both directly and through the loyalty variable effect on brand equity. Yoo et al. (2000) performed a study on cultural differentiation between two countries, United States and Korea for 12 different brands and showed that loyalty to the brand had positive impact on brand equity but the effect was not the same in these two markets. By review of literature related to the field of loyalty, there are many definitions for the term provided. However, two main approaches can be identified, including behavioral loyalty and attitudinal loyalty.

\section{Unethical behavior}

Ferrell and Gresham (1985) state that ethical or unethical behaviors emerge because of individual factors, thinking others are important in the organization and getting the opportunity for doing unethical.

\section{Social Responsibility}

Corporate social responsibility can be defined as a strategic way of managing the market to empower growth and sustainable development of economics, environment and social. According to Steinman 
and Wolfram (2012) unethical behavior does not impact on consumer attitudes toward the brand. The findings of Ingram et al. (2005) suggest that committed customers forgive unethical behavior of companies up to a certain degree but when the loss increases a high level of dissatisfaction is expressed. Barnes (2011) state that corporate social responsibility (CSR) have a positive impact on consumer behavior. Satisfaction may influence on consumer`s trust and so it influences on loyalty and trust variables. Hamidi et al. (2012) suggest that the two dimensions of responsibility and dynamism could have significant impact on brand equity. The findings of Mortazavi et al. (2010) show that social responsibility towards the social and non-social stakeholders, employees, customers and the government is strong prediction for organizational commitment changes. The results of Ebrahimi et al. (2009) indicate that price, family, advertising and distribution influence indirectly through dimensions of brand equity on brand equity. Brand awareness, brand associations, perceived quality and brand loyalty influence directly on loyalty and also directly effect on brand equity. They also suggests that there was a positive relationship between the ethical marketing and consumer food purchasing behavior. Román and Ruiz (2005) findings suggest that ethical sales behavior could lead to satisfaction, trust and loyalty of customers to the respective companies. Parhizgar and Abedi (2012) conclude that brand loyalty and brand associations had a direct impact on brand equity.

In this study we examine the effects of unethical behavior on brand equity. With regard to the findings of previous research by Aaker (1991) dimensions of brand equity include brand association (evoke), perceived quality and loyalty. Dimensions of unethical behavior include bribery, cheating, deception, how to interact with colleagues, how to act social behavior, irresponsibility and lack of commitment to the company (Lassar et al., 1995 ). Fig. 1 shows the proposed model.

\begin{tabular}{|l|}
\hline \multicolumn{1}{|c|}{ Unethical behavior } \\
\hline \multicolumn{1}{|c|}{$\uparrow$} \\
\hline 1. Bribery \\
2. Cheating \\
3. Deception \\
4. Interact with colleagues \\
5. Act as social behavior \\
6. Uncommitted to firm \\
7. Irresponsibility \\
\hline
\end{tabular}

\begin{tabular}{|ll|}
\hline \multicolumn{2}{|c|}{ Brand equity } \\
\hline \multicolumn{1}{|c|}{$\uparrow$} \\
\hline 1. & Awareness \\
2. & Perceived quality \\
3. & Loyalty \\
\hline
\end{tabular}

Fig. 1. The propose study

According to Fig. 1, the following hypotheses are considered.

$\mathrm{H}_{1}$ : Unethical behavior has negative relationship with brand equity.

$\mathrm{H}_{2}$ : Bribery has negative relationship with brand equity.

$\mathrm{H}_{3}$ : Cheating has negative relationship with brand equity.

$\mathrm{H}_{4}$ : Fraud has negative relationship with brand equity.

$\mathrm{H}_{5}$ : How to interact with colleagues has relationship to brand equity.

$\mathrm{H}_{6}$ : The social behavior has relationship with brand equity.

$\mathrm{H}_{7}$ : Lack of commitment to the company has negative relationship with brand equity.

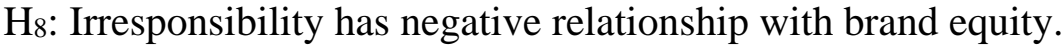

$\mathrm{H}_{9}$ : Unethical behavior has negative relationship with awareness and associations of brand.

$\mathrm{H}_{10}$ : Unethical behavior has negative relationship with perceived quality.

H11: Unethical behavior has negative relationship with customer loyalty.

\section{Research Methodology}

In this study, we focus on the dealers of insurance company in Mazandaran province. There are 367 dealers across the province and by using the Cochran method187 representative across the province 
were selected and the questionnaires were distributed among the branches. The way of sampling was simple random sampling. 64\% of respondents were male and $36 \%$ female, $80 \%$ under 40 years of age and $41 \%$ have an associate's degree and $37 \%$ have a bachelor's degree. The questionnaire was revised by a number of experts and validity was confirmed. For this study since we did not have any designed and standard questionnaire to evaluate dependent and independent variables, in first step we use Exploratory factor analysis by SPSS to get high reliability questions. In the second step to study about correlation of the independent and dependent variables we use confirmatory factor analysis and Structural Equation Modeling (SEM).

Steps of designing questionnaire are as follows:

Step 1: In this step for unethical behavior 8 dimensions and for brand equity 3 dimensions was defined. Step 2: After defining dimensions, list of criteria was produced to carefully evaluate various aspects of each dimension. Selection criteria for each aspect of dimensions was based on internal and external research of the study variables. For ethical behavior variable 33 questions and for brand equity 21 questions were designed.

Step 3: After designing two questionnaires, 30 of them were distributed and the data was analyzed by SPSS and then questions was revised based on result and comments of experts. Inappropriate questions with lower than 50\% KMO were removed.

Step 4: Revised questionnaire again was distributed among 50 people and then was analyzed. After modifying questions removing inappropriate ones, the KMO was $91 \%$ for unethical behavior variable and $92 \%$ for brand equity. As noted above the level of reliability in research quality is very good and can be quite to be trusted.

\section{Analysis of findings}

Since our data are normally distributed, we used parametric tests and given that the present paper we have used the Likert scale interval to measure of the direction, intensity and relationship of it between two variables we use the Pearson correlation coefficient. In this study after collecting and summarizing the data using LISREL 8.5 software and Spss 16 through descriptive and inferential statistical indicators we analyzed the data. In the first section, the data collected using descriptive statistics, descriptions and then in order to create an acceptable measurement model, confirmatory factor analysis using LISREL software, all of the hidden variables is determined. Then after checking the normality of distribution using SPSS statistical correlation between the independent and dependent variables are examined. Finally, using path analysis, causal relationships between research hypotheses are tested. Then after checking the normality of distribution using SPSS statistical correlation between the independent and dependent variables are examined. In the end, using path analysis, causal relationships between research hypotheses are tested.

\section{Analysis Assumptions}

The present study explores the relationship between unethical behaviors on brand equity check. Eleven hypotheses were proposed for this purpose. To test the hypothesis at first the correlation between independent, mediators and dependent variables should be examined. As in the previous section the normality of distribution was proved (Kolmogorov-Smirnov test) using LISREL, correlation between variables was tested. We used path analysis to examine the causal relationship between independent and dependent variables and confirming the whole model. The path analysis was conducted using software LISREL8.5. The results of the LISREL output shows that the ratio of chi-square to degrees of freedom is less than three and other suitability indicators confirmed the model. T-value test of model shows that unethical behavior had a direct and positive impact on brand equity while the t-value is greater than two, the cases are approved. Table 1 shows the t-value significant amount and summarizes the hypothesis result. 
Table 1

The summary of Pearson correlation test matrix dimension to the brand and unethical behavior

\begin{tabular}{lcc}
\hline Brand dimension & T-value (Sig.) & Pearson correlation \\
\hline Awareness & 0.000 & 0.619 \\
Perceived value & 0.000 & 0.671 \\
Customer loyalty & 0.000 & 0.607 \\
Creating value for customers & 0.000 & 0.433 \\
\hline
\end{tabular}

According to the test result because the amount of significant for each dimension is lower than 0.01 with the level of assurance $0.99(\alpha=0.01)$, the $\mathrm{H}_{0}$ was rejected and $\mathrm{H}_{1}$ was confirmed and we can trust on completely experimentally and statistically. Also according to the values 0.433 (creating value for consumers), 0.619 (associations and consumer awareness), 0.671 (perceived quality) and 0.607 (customer loyalty), kind of relationship obtained is positive, intensive and directly that when the ethical behavior is dominant in the company the amount of each dimensions will be more intensive. Based on the correlation between their dimensions, the greatest impact of unethical behavior is on the perceived quality of a company's.

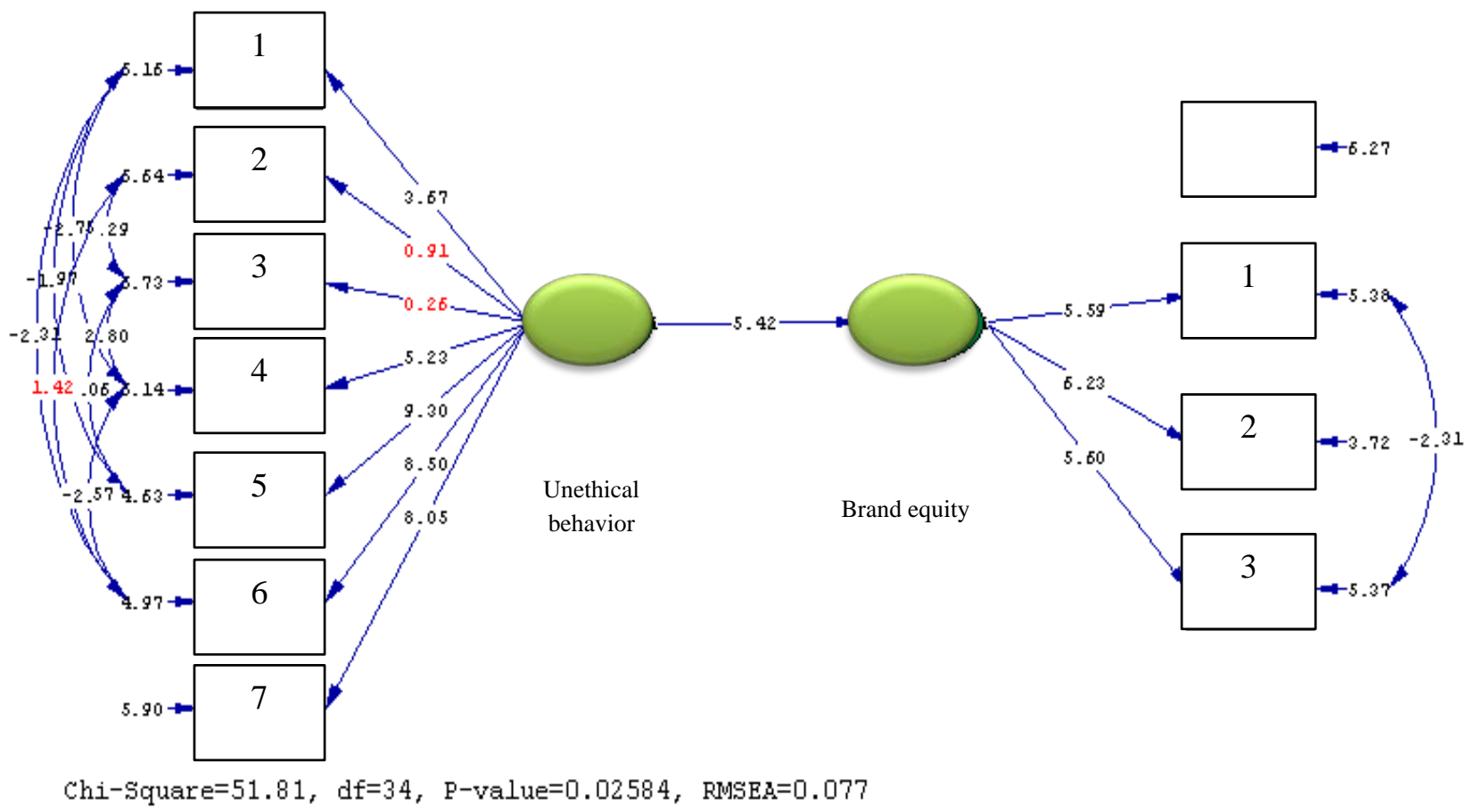

1. Bribery

2. Cheating

3. Deception

4. Interact with colleagues

5. Act as social behavior

6. Uncommitted to firm

7. Irresponsibility
1. Awareness

2. Perceived quality

3. Loyalty

Fig. 2. The results of SEM implementation

As we can observe from the results of Fig. 2, Chi-Square value is equal 51.81 with $\mathrm{df}=34$ and P-value of 0.02584 , which means the results are statistically significant. In addition, RMSEA value is within acceptable level. 


\section{Discussion and conclusion}

As we can observe from the results of Fig. 2, the effects of cheating and deception on unethical behaviors were not confirmed but the effects of other factors, bribery, interact with colleagues, act as social behavior, uncommitted to firm and irresponsibility on unethical behavior were confirmed. In addition, three components of Awareness, Perceived quality and Loyalty have positive relationship with brand equity. Monday (2011) reported that ethical sales behavior could lead to more satisfaction, trust and customer loyalty to the respective vendor company, which are consistent with the findings of this survey.

Mortazavi et al. (2010) also performed an investigation on the role of moderator of some variables on the relationship between social responsibility and commitment to corporate social responsibility for a case study of food processing companies in city of Mashhad, Iran. They also reported similar results of our survey. However, Steinman and Wolfram (2012) showed that unethical behavior was unaffected on consumer attitudes toward the brand while in this study the opposite side was proved and showed that the impact of unethical behavior had a strong relationship with the brand equity. Nevertheless, the results of our survey are consistent with other results such as Oliver (2010), Lin (2010), Mohd Yasin et al. (2005) and Nobre (2008).

Behavior and attitudes of staff and people in an organization and to customers and clients is an important factor and its importance is obvious. We hope this study could shed some light on learning more about Iranian culture.

\section{Acknowledgement}

The authors would like to thank the anonymous referees for constructive comments on earlier version of this paper.

\section{References}

Aaker, D. A. (1991). Managing Brand Equity. The Free Press, New York, NY.

Aaker, D. A. (1996). Building Strong Brands. Free Press, New York.

Aaker, J. L. (1997). Dimensions of brand personality. Journal of marketing research, 34, 347-356.

Alwani, M., \& Ghasemi, R. (1997). Management and Corporate Social Responsibility. Public Administration Training Centre Publisher, Tehran. (In Persian).

Atilgan, E., Aksoy, S., \& Akinci, S. (2005). Determinants of the brand equity: A verification approach in the beverage industry in Turkey. Marketing intelligence \& planning, 23(3), 237-248.

Backman, S. J. (1988). The utility of selected personal and marketing characteristics in explaining consumer loyalty to selected recreation services. Dissertation Abstracts International, A (Humanities and Social Sciences),49(6).

Barnes, A.-J. (2011). Corporate Social Responsibility and its effects on Band Trust. A thesis Submitted to Auckland University of Technology.

Bravo Gil, R., Fraj Andres, E., \& Martinez Salinas, E. (2007). Family as a source of consumer-based brand equity. Journal of Product \& Brand Management, 16(3), 188-199.

Brunk, K. H. (2010). Exploring origins of ethical company/brand perceptions-A consumer perspective of corporate ethics. Journal of Business Research,63(3), 255-262.

Cardy, R. L., \& Selvarajan, T. T. (2004). Assessing ethical behavior: Development of a behaviorally anchored rating scale. In 47th Midwest Academy of Management Meeting.

Davar,V., Zohouri, B. (2011). Effects of the value of relationship marketing on customer loyalty and brand mobile phones. Journal of Business Management, 3(8), 170-151.

Ebrahimi, A., Kheiri, B., \& Niaki, S. (2009). Evaluation of factors effect on brand equity based on customer view. Journal of Marketing Management, 4(7), 184-159. (In Persian). 
Ebrahim, A., \& Roudany, A. (2009). The role of ethics in marketing consumer food purchasing behavior. Journal of Ethics in Science and Technology, 2(1), 29-39.

Ferrell, O., \& Gresham, L. G. (1985). A contingency framework for understanding ethical decision making in marketing. The Journal of Marketing, 49(3), 87-96.

Gill, M. S., \& Dawra, J. (2010). Evaluating Aaker's sources of brand equity and the mediating role of brand image. Journal of Targeting, Measurement and Analysis for Marketing, 18(3), 189-198.

Hamidi, A.H., Karimi Alavijeh, M.R., \& Dary, B. (2006). Development of the relation between customer-based brand equity and brand performance on the market: A case study of dairy brands in the market. Journal of Economics and New Business, 15, 76-52. (In Persian).

Hamidi, M. R., Karimi Alavijeh, M., \& Rezaei, M. (2012). Dimensions of personality and brand equity and ecological mitigation moral traits. Scientific-Research Publication of Modern Marketing, 3(6), 35-50. (In Persian).

Haghighi, K., Abbasnejad, S., Sehat, S. (2011). Ethical sales behavior relationship with customer loyalty in life insurance: Case of an insurance company. Insurance Journal, 26(4), 141-154. (In Persian).

Ingram, R., Skinner, S. J., \& Taylor, V. A. (2005). Consumers’ evaluation of unethical marketing behaviors: The role of customer commitment. Journal of Business Ethics, 62(3), 237-252.

Keller, K. L., Parameswaran, M. G., \& Jacob, I. (2011). Strategic brand management: Building, measuring, and managing brand equity. Pearson Education India.

Kotler, P. (2000). Marketing management: The millennium edition (pp. 87-103). Upper Saddle River, NJ: Prentice-Hall.

Lassar, W., Mittal, B., \& Sharma, A. (1995). Measuring customer-based brand equity. Journal of Consumer Marketing, 12(4), 11-19.

Louis, D., \& Lombart, C. (2010). Impact of brand personality on three major relational consequences (trust, attachment, and commitment to the brand).Journal of Product \& Brand Management, 19(2), 114-130.

Lin, L. Y. (2010). The relationship of consumer personality trait, brand personality and brand loyalty: an empirical study of toys and video games buyers. Journal of Product \& Brand Management, 19(1), 4-17.

Oliver, R. L. (2010). Satisfaction: A behavioral perspective on the consumer. ME sharpe.

Monday, O. (2011). Consumers’ Perception of Corporate Social Responsibility. European Journal of Humanities and Social Sciences Vol, 4(1).

Mohd Yasin, N., Nasser Noor, M., \& Mohamad, O. (2007). Does image of country-of-origin matter to brand equity?. Journal of Product \& Brand Management, 16(1), 38-48.

Mortazavi, S., Naseri Pourazad, A., Amirrazavi, P., \& Sadeghi Moghadam, M. (2010). An investigation on the role of moderator of some variables on the relationship between social responsibility and commitment to corporate social responsibility, Case study: food processing companies in Mashhad. Mashhad University Journal of Social Sciences and Humanities Literature, 193-217.

Nobre, H. (2008). Brand relationship: a personality approach. PhD thesis in Business Catholic Portuguesa University.

Pappu, R., Quester, P. G., \& Cooksey, R. W. (2005). Consumer-based brand equity: improving the measurement-empirical evidence. Journal of Product \& Brand Management, 14(3), 143-154.

Parhizgar, M., \& Abedi, I. (2012). Effect of brand equity on brand equity model in an acre of view of consumers (Case study Brand Samsung). Journal of the Great Reviews, 53, 71-61. (In Persian).

Raashnvady, Y., \& Dehnavi, M. (2008). Life insurance role in promoting social justice and welfare. A New Monthly Insurance World, 121, 21-33.

Román, S., \& Ruiz, S. (2005). Relationship outcomes of perceived ethical sales behavior: the customer's perspective. Journal of Business Research,58(4), 439-445.

Steinman, R. B., \& Wolfrom, B. T. (2012). The Effect of Brands' Unethical Actions on Consumers' Attitudes in the Fast Moving Consumer Goods Domain. Business Management Dynamics, 2, 32-39.

Taylor, S. A., Celuch, K., \& Goodwin, S. (2004). The importance of brand equity to customer loyalty. Journal of product \& brand management, 13(4), 217-227. 
610

Wood, L. (2000). Brands and brand equity: definition and management. Management decision, 38(9), 662-669.

Yoo, B., Donthu, N., \& Lee, S. (2000). An examination of selected marketing mix elements and brand equity. Journal of the academy of marketing science,28(2), 195-211. 